\title{
Hubungan antara Kegiatan Permainan Lempar Bola terhadap Kemampuan Motorik Kasar Anak
}

\section{Sri Sulastri}

RA Nurul Bayan Garut

Desa Hegarsari, Kecamatan Kadungora, Kabupaten Garut

Email: sulastrisri927@gmail.com

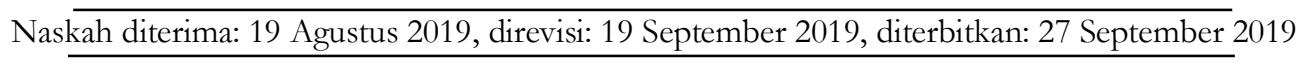

\begin{abstract}
Abstrak
Penelitian ini bertujuan untuk mengetahui hubungan antara kegiatan permainan lempar bola terhadap kemampuan motorik kasar anak di kelompok B RA Nurul Bayan Garut. Penelitian ini menggunakan pendekatan kuantitatif dengan metode korelasional, alat pengumpul data dalam penelitian ini yaitu berupa observasi, wawancara, dan dokumentasi. Adapun teknik analisis data yang digunakan adalah analisis statistik non parametrik. Subjek pada penelitian ini adalah seluruh siswa kelompok B RA Nurul Bayan Garut dengan jumlah 16 anak ditetapkan sebagai responden penelitian. Uji persyaratan analisis menunjukkan bahwa kedua variabel berdistribusi normal. Hasil analisis data menunjukkan bahwa kegiatan permainan lempar bola di kelompok B RA Nurul Bayan Garut, berada pada kategori baik dengan nilai rata-rata sebesar 77. Sedangkan kemampuan motorik kasar anak di kelompok B RA Nurul Bayan Garut berada pada kategori cukup dengan nilai rata-rata sebesar 66. Hubungan antara kegiatan permainan lempar bola terhadap kemampuan motorik kasar anak diperoleh angka koefisien korelasi sebesar 0,76. Angka koefisien korelasi ini termasuk pada kategori kuat/tinggi, karena berada pada interval 0,600-0,799. Hasil uji signifikansi diperoleh harga t-hitung $=4,369>\mathrm{t}$-tabel $=2,145$. Artinya Ha diterima, dengan kata lain ada hubungan yang signifikan antara kegiatan permainan lempar bola terhadap kemampuan motorik kasar anak. Adapun besarnya kontribusi/pengaruh kegiatan permainan lempar bola terhadap kemampuan motorik kasar anak sebesar 58\%, hal ini menunjukkan bahwa $42 \%$ kemampuan motorik kasar anak dipengaruhi faktor lain.
\end{abstract}

Kata kunci: anak usia dini, permainan lempar bola, kemampuan motorik kasar anak. 


\begin{abstract}
This study aims to determine the relationship between the activities of throwing a ball on the gross motor skills of children in group B RA Nurul Bayan Garut. This study uses a quantitative approach with the correlational method, the data collection tool in this study in the form of observation, interviens, and documentation. The data analysis technique used is non-parametric statistical analysis. The subjects in this study were all students of group B RA Nurul Bayan Garut with a total of 16 children assigned as research respondents. Test requirements analysis shows that the two variables are normally distributed. The results of data analysis showed that the activities of throwing a ball in group $B \mathrm{R} A$ Nurul Bayan Garut, were in the good category with an average value of 77 . While the gross motor skills of children in group $B \mathrm{R} A$ Nurul Bayan Garut were in the sufficient category with an average value of 66. The relationship between ball throwing activities and children's gross motor skills obtained by the correlation coefficient of 0.76 . This correlation coefficient number is included in the category of strong / high, because it is in the interval 0,6000,799. Significance test results obtained by the price of $t$-count $=4.369>t$-table $=2.145$. This means that $\mathrm{Ha}$ is accepted, in other words there is a significant relationship between the activities of throwing a ball on the gross motor skills of children. The magnitude of the contribution / influence of the activities of throwing a ball on children's gross motor skills by 58\%, this shows that $42 \%$ of children's gross motor skills are influenced by other factors.
\end{abstract}

Keywords: early childhood, ball throwing games, children's gross motor skills.

\title{
Pendahuluan
}

Pendidikan dapat diartikan secara sempit dan dapat pula diartikan secara luas. Secara sempit, pendidikan adalah suatu hal yang diberikan kepada anak-anak sampai dewasa, yaitu berupa bimbingan. Sedangkan dalam arti luas adalah upaya penanaman dan pengembangan nilai-nilai bagi anak didik yang menyangkut proses perkembangan manusia. Sehingga anak akan menjadi orang pandai, baik, menjadi orang yang berguna bagi lingkungannya dan mampu bertahan hidup, semua itu bagian dari nilai-nilai yang terkadung di dalam pendidikan tersebut (Nata, 2003: 10).

Secara institusional, pendidikan anak usia dini juga adalah salah satu bentuk pendidikan yang diselenggarakan dengan menitikberatkan pada peletakan dasar ke arah pertumbuhan dan perkembangan anak. Masa usia dini adalah masa emas (golden age) dalam rentang perkembangan seorang individu. Pada masa ini, tumbuh kembang anak berkembang sangat pesat, baik dari segi emosi, fisik-motorik, psikososial ataupun kognitif. Pada masa ini, perkembangan anak berjalan dengan pesat, masa ini merupakan masa yang 
fundamental bagi kehidupan individu, perkembangan fisik-motorik anak sangat menonjol pada masa ini (Lismadiana, 2013: 4).

Menurut Sumantri (2005: 48) perkembangan motorik adalah perubahan gerak dari anak sejak lahir sampai dewasa yang melibatkan berbagai aspek perilaku. Sedangkan menurut Sujiono (2014: 9) perkembangan motorik adalah pengendalian gerak tubuh dan perkembangan unsur kematangan, dengan berjalannya kematangan syaraf dan otot dengan baik, maka keterampilan motorik akan berkembang dengan optimal.

Sunaryo (2007: 113) mengungkapkan bahwa kemampuan motorik kasar adalah kemampuan gerak yang ada di dalam tubuh dan menggunakan otot-otot besar. Menurut Sujiono B. (2007: 13) motorik kasar adalah kemampuan sesorang yang melibatkan koordinasi sebagian besar dari tubuh. Gerakan motorik kasar adalah kemampuan anak yang membutuhkan koordinasi dari sebagian besar tubuhnya. Oleh karena itu, biasanya dilakukan oleh otot-otot besar yang sangat membutuhkan tenaga (Depdiknas, 2007: 1). Perkembangan motorik kasar anak dapat dilatih dengan berbagai teknik dan cara yang menarik dan menyenangkan bagi anak, salah satunya adalah dengan permainan. Montolalu (Erlinda, 2014: 2) mengatakan bahwa aspek motorik kasar anak dapat dikembangkan melalui permainan, yaitu salah satunya adalah dengan permainan lempar bola.

Berdasarkan hasil pengamatan awal di RA Nurul Bayan Garut menunjukkan fenomena yang menarik untuk dikaji. Kegiatan-kegiatan olah tubuh yang sering dilaksanakan di RA Nurul Bayan Garut diantaranya, permainan lempar bola, senam, bermain lompat tali dan kegiatan olah tubuh lainnya. Permainan olah tubuh tersebut sangat penting untuk menguatkan otot-otot besar maupun kecil di dalam tubuh anak. Permainan lempar bola dilakukan setiap satu minggu satu kali, namun di sisi lain kemampuan motorik kasar anak masih rendah, karena memperoleh nilai rata-rata sebesar 54, sedangkan permainan lempar bola memperoleh nilai rata-rata sebesar 73. Penulis menemukan fenomena rendahnya kemampuan motorik kasar anak pada saat pembelajaran. Hal tersebut dilihat dari anak kurang aktif saat pembelajaran motorik kasar, anak terlihat diam dan jarang bergerak walaupun kondisi fisiknya terlihat sehat dan gerakan keseimbangan dan koordinasi pada sebagian anak masih belum terlihat.

Melempar bola merupakan kegiatan yang menggunakan satu atau dua tangan yang termasuk ke dalam keterampilan manipulatif dengan tujuan untuk melontarkan bola menjauh badan ke udara (Erlinda, 2014: 29). Menurut Soeparman (1993: 324) kemampuan melempar bola adalah kemampuan dalam mempertimbangkan jarak yang sangat jauh untuk 
melakukan lemparan. Besarnya gaya yang digunakan dan kecepatan tangan pada saat pelepasan berhubungan dengan kecepatan jarak yang dilemparkan. Pertumbuhan fisik terutama pada Perkembangan lengan dan bahu bisa meningkat saat sesorang melempar bola. Kemampuan melempar terbagi ke dalam dua aspek perkembangan yaitu bersifat kuantitatif dan kualitatif. Semakin jauh lemparannya disebut dengan perkembangan yang bersifat kuantitatif. Sedangkan yang disebut kualitas gerakan melemparnya, atau semakin baik lemparan semakin efesien pula lemparannya, itu termasuk perkembangan yang bersifat kualitatif (Sudjarwo, 1992: 120).

Mahendra (2000: 11) mengatakan bahwa mengoper/melempar bola memerlukan tenaga yang dihasilkan dari tubuh saat bergerak ke depan kemudian terjadi penyaluran atau penggabungan tenaga pada lengan, dan pergelangan tangan. Untuk operan jarak jauh atau untuk mengecoh lawan yaitu dengan menggunakan operan satu tangan. Hurlock (1978: 160) mengemukakan bahwa anak bisa memegang benda kecil di sekitar tangan dimulai dari umur kurang dari 6 bulan. Sedangkan Satyaningdharma mengungkapkan bahwa permainan lempar bola adalah permainan yang dirancang untuk pendidikan jasmani yang mudah dilakukan dan dikaji melalui penelitian pengembangan baik dari cara bermain, peraturan jumlah pemain serta area lapangan untuk memberi daya tarik bagi anak-anak. Permainan ini bertujuan untuk mendorong siswa lebih berkomunikasi dengan teman (http://satyaningdharmablogspot.com, akses 10 Agustus 2019).

Berdasarkan pemaparan di atas, penulis merasa tertarik untuk melakukan penelitian melalui sebuah judul "Hubungan Kegiatan Permainan Lempar Bola dengan Kemampuan Motorik Kasar Anak". Adapun tujuan penelitian ini adalah untuk mengetahui hubungan kegiatan permainan lempar bola dengan kemampuan motorik kasar anak di kelompok B.

\section{Metodologi}

Metode yang digunakan dalam penelitian ini adalah metode korelasi yaitu suatu penelitian yang melibatkan tindakan pengumpulan data guna menentukan, apakah ada hubungan dan tingkat hubungan antara dua variabel atau lebih. Penelitian korelasional menurut Sukardi (2003: 166) adalah penelitian yang bertujuan untuk mengetahui tingkat hubungan variabel bebas dengan variabel terikat. Penelitian korelasi merupakan salah satu bagian dari penelitian ex-postfacto karena penelitian tidak memanipulasi keadaan dari variabel yang ada dan langsung mencari keberadaan hubungan dan tingkat hubungan variabel yang direfleksikan dalam koefisien korelasi. 
Jenis data dalam penelitian ini berupa data kualitatif dan kuantitatif. Data kualitatif adalah data yang diperoleh dari hasil wawancara dan dokumentasi. Sedangkan data kuantitatif adalah penerapan prosedur kerja secara baku dan transfer data ke dalam angkaangka numerikal khususnya yang menyangkut atribut dan kualitas subjek yang diolah dengan metoda statistika.

Analisis data secara kualitatif diperoleh dari hasil wawancara, dan dokumentasi. Sedangkan analisi data secara kuantitatif diperoleh dari hasil observasi, instrumen observasi yang digunakan sebagai alat pengumpul data diujicobakan terlebih dahulu di TAAM Bani Umar Kota Bandung, kemudian datanya dianalisis validitas dan reliabilitasnya untuk mendapatkan instrumen yang layak sebagai alat-alat pengumpul data. Dari 40 item diperoleh 9 item yang tidak valid, maka instrumen observasi yang digunakan untuk menggali data Kegiatan Permainan Lempar Bola (Variabel X) dan Kemampuan Motorik Kasar Anak (Variabel Y) berjumlah 31 item. Uji coba pada penelitian ini bertujuan untuk mengetahui tingkat valisitas dan reliabilitas instrumen yang digunakan. Validitas adalah suatu ukuran yang menunjukkan tingkat-tingkat kevalidan atau kebenaran sesuatu instrumen. Suatu instrumen yang valid atau benar mempunyai validitas tinggi. Sebaliknya, instrumen yang kurang valid berarti memiliki validitas rendah (Suharsimi, 2013: 213). Analisis data korelasi menggunakan analisis statistik non parametrik dengan rumus korelasi Spearman Rank.

Penelitian dilakukan di kelompok B RA Nurul Bayan Garut pada semester ganjil Tahun Ajaran 2019/2020. Dengan waktu penelitian dimulai dari bulan Agustus sampai dengan selesai.

\section{Hasil dan Diskusi}

Berdasarkan hasil penelitian, data kegiatan permainan lempar bola yang diperoleh dari pengisian lembar observasi yang terdiri dari 3 indikator yaitu 1) ketepatan; 2) keseimbangan; dan 3) kelincahan. Dari tiga indikator ini dikembangkan menjadi delapan sub indikator, yaitu: 1) melempar bola tepat pada sasaran; 2) melambungkan bola; 3) menangkap bola; 4) mempertahankan posisi tubuh; 5) melempar bola dengan dua tangan; 6) melempar bola ke berbagai arah; 7) menangkap bola dari berbagai arah; dan 8) menghindari lawan. Dengan jumlah pertanyaan yaitu 15 item, instrumen observasi dilengkapi dengan empat alternatif penilaian, dimulai dari skor terendah 1 bagi anak yang tingkat pencapaiannya pada kategori BB (Belum Berkembang), skor 2 bagi anak yang tingkat pencapaiannya pada kategori MB 
(Mulai Berkembang), skor 3 bagi anak yang tingkat pencapaiannya pada kategori BSH (Berkembang Sesuai Harapan), dan skor 4 bagi anak yang tingkat pencapaiannya pada kategori BSB (Berkembang Sangat Baik). Pada langkah pengolahan data, setiap item dicari nilai rata-ratanya dan diinterpretasikan pada skala 0-100 seperti pada tabel berikut ini:

Tabel 1. Interpretasi Skor Rata-rata Indikator

\begin{tabular}{|c|c|c|}
\hline No & Skala & Interpretasi \\
\hline 1 & $80-100$ & Sangat Baik \\
\hline 2 & $70-79$ & Baik \\
\hline 3 & $60-69$ & Cukup \\
\hline 4 & $50-59$ & Kurang \\
\hline 5 & $0-49$ & Gagal \\
\hline
\end{tabular}

Tabel 2. Data Hasil Kegiatan Permainan Lempar Bola

\begin{tabular}{llll}
\hline No & Indikator & Skor & Kategori \\
\hline 1 & Melempar Bola tepat pada Sasaran & 84 & Sangat Baik \\
2 & Melambungkan Bola & 67 & Cukup \\
3 & Menangkap Bola & 76 & Baik \\
4 & Mempertahankan posisi tubuh & 77 & Baik \\
5 & Melempar Bola dengan Dua Tangan & 75 & Baik \\
6 & Melempar Bola ke Berbagai Arah & 75 & Baik \\
7 & Menangkap Bola dari Berbagai Arah. & 82 & Sangat Baik \\
8 & Menghindari Lawan & 78 & Baik \\
Rata-rata & 77 & Baik
\end{tabular}

Berdasarkan nilai rata-rata dari delapan indikator variabel X (Kegiatan Permainan Lempar Bola), maka dapat dihitung nilai rata-rata akhir, yaitu: $84+67+76+77+75+75$ $+82+78=614: 8=77$. Angka tersebut jika dikonsultasikan pada tabel interpretasi termasuk ke dalam kategori baik karena berada pada interval 70-79, artinya Kegiatan Permainan Lempar Bola termasuk ke dalam kategori baik.

Berdasarkan hasil penelitian kondisi tubuh anak terolah dengan baik melalui kegiatan permainan lempar bola, dalam permainan lempar bola anak harus memiliki keterampilan untuk menyalurkan tenaga terhadap bola yang menghasilkan daya atau kekuatan, dasar gerakan melempar bola rata-rata sudah dikuasai oleh anak, teknik dalam permainan harus sudah dikuasai agar dapat memainkan permainan dengan baik dan lancar, sehingga permainan akan lebih mudah dan menyenangkan bagi anak. Begitu juga dalam permainan lempar bola anak harus memiliki teknik dasar yang dikuasai. Teknik melempar bola 
berdasarkan tujuannya dibedakan menjadi tiga yaitu lemparan untuk operan (passing), melambungkan bola, dan lemparan kepada lawan/sasaran (Mirman, 2005: 78).

Sedangkan data kemampuan motorik kasar anak yang diperoleh dari pengisian lembar observasi yang terdairi dari 5 indikator yaitu: 1) melakukan gerakan tubuh secara terkoordinasi untuk melatih kelenturan, keseimbangan, dan kelincahan; 2) melakukan koordinasi gerakan kaki-tangan-kaki-kepala dalam menirukan tarian atau senam; 3) melakukan permainan fisik dengan aturan; 4) terampil menggunakan tangan kanan dan kiri; dan 5) melakukan kegiatan kebersihan diri. Dari lima indikator ini dikembangkan menjadi sembilan sub indikator, yaitu: 1) berdiri di atas satu kaki; 2) melakukan gerakan kombinasi; 3) berlari dari satu tempat ke tempat lain; 4) mengayunkan tangan; 5) tidak melewati batas garis; 6) mengikuti permainan sesuai aturan waktu; 7) menekuk kedua tangan; 8) merapihkan alat-alat permainan yang sudah dipakai; dan 9) mencuci tangan dan kaki setelah selesai permainan. Dengan jumlah pertanyaan yaitu 16 item, instrumen observasi dilengkapi dengan empat alternatif penilaian, dimulai dari skor terendah 1 bagi anak yang tingkat pencapaiannya pada kategori BB (Belum Berkembang), skor 2 bagi anak yang tingkat pencapaiannya pada kategori MB (Mulai Berkembang), skor 3 bagi anak yang tingkat pencapaiannya pada kategori BSH (Berkembang Sesuai Harapan), dan skor 4 bagi anak yang tingkat pencapaiannya pada kategori BSB (Berkembang Sangat Baik). Pada langkah pengolahan data, setiap item dicari nilai rata-ratanya dan diinterpretasikan pada skala 0 100 yang dapat dilihat pada tabel 1. di atas.

Tabel 3. Data Hasil Kemampuan Motorik Kasar Anak

\begin{tabular}{llll}
\hline No & Indikator & Skor & Kategori \\
\hline 1 & Berdiri di Atas Satu Kaki & 62 & Cukup \\
2 & Melakukan Gerakan Kombinasi & 59 & Kurang \\
3 & Berlari dari Satu Tempat ke Tempat Lain & 66 & Cukup \\
4 & Mengayunkan Kedua Tangan & 72 & Baik \\
5 & Tidak Melewati Batas Garis & 69 & Cukup \\
6 & Mengikuti Permainan Sesuai Aturan Waktu & 68 & Cukup \\
7 & Menekuk Kedua Tangan & 59 & Kurang \\
8 & Merapihkan Alat-alat Permainan yang Sudah Dipakai & 72 & Baik \\
9 & Mencuci Tangan dan Kaki Setelah Selesai Permainan. & 68 & Cukup \\
Rata-rata & 66 & Cukup \\
\hline
\end{tabular}

Berdasarkan nilai rata-rata dari sembilan indikator variabel Y (Kemampuan Motorik Kasar Anak), maka dapat dihitung nilai rata-rata akhir, yaitu: $62+59+66+72+69+68$ $+59+72+68=595: 9=66$. Angka tersebut jika dikonsultasikan pada tabel interpretasi termasuk ke dalam kategori cukup karena berada pada interval 60-69 artinya kegiatan permainan lempar bola termasuk ke dalam kategori cukup. 
Berdasarkan hasil penelitian sebagian besar anak memiliki perkembangan motorik kasar yang cukup baik, tetapi terdapat beberapa anak yang belum optimal dalam perkembangan motorik kasarnya, seperti pada indikator "Melakukan Gerak Kombinasi" dan indikator "Menekuk Kedua Tangan", saat kegiatan berlangsung terlihat ada beberapa anak yang kurang antusias dan memilih untuk bermain sendiri di ruang kelas, sebagian anak masih belum mampu melakukan gerakan keseimbangan dan gerakan koordinasi. Perkembangan anak yang satu dengan yang lainnya berbeda-beda, hal ini karena perkembangan motorik kasar anak dipengaruhi oleh beberapa faktor. Sejalan dengan pendapat (Wiyani, 2014: 38) bahwa terdapat faktor-faktor yang mempengaruhi kemampuan motorik kasar anak, diantaranya: faktor makan, faktor pemberian stimulus, faktor kesiapan fisik, faktor jenis kelamin, faktor budaya.

Untuk mengetahui Hubungan antara Kegiatan Permainan Lempar Bola terhadap Kemampuan Motorik Kasar Anak, terlebih dahulu dilakukan uji persyaratan yaitu uji normalitas dan uji regresi linier. Dalam menghitung uji normalitas dilakukan dengan perhitungan chi kuadrat (x2). Untuk Variabel X (Kegiatan Permainan Lempar Bola) diperoleh mean $=77,5$; standar deviasi $=7,52$; nilai chi kuadrat $(\mathrm{x} 2$ hitung $)=1,857$; chi kuadrat $x 2$ tabel $=7,815$ dengan $\mathrm{db}=3$ pada taraf signifikansi 5\%. Karena (x2hitung) $=$ $1,857<\mathrm{x} 2$ tabel $=7,815$; maka data tentang Kegiatan Permainan Lempar Bola berdistribusi normal. Kemudian untuk uji normalitas Variabel Y (Kemampuan Motorik Kasar Anak) diperoleh mean $=66,06$; dan standar deviasi $=8,41$; nilai chi kuadrat $(\mathrm{x} 2 \mathrm{hitung})=9,182$; dan chi kuadrat $x 2$ tabel $=9,488$ dengan $\mathrm{db}=4$ pada taraf signifikansi $5 \%$. Karena $(\mathrm{x} 2$ hitung $)=9,182<\mathrm{x} 2$ tabel $=9,488$, maka data tentang Kemampuan Motorik Kasar Anak berdistribusi normal. Adapun uji regresi linier dari kedua variabel diperoleh Fhitung $=244,41$; Ftabel $=4,78$ dengan $\mathrm{db}=9 / 5$ pada taraf signifikansi 5\%. Karena Fhitung $=$ 244,41 $>$ Ftabel $=4,78$, maka dapat disimpulkan bahwa regresi $\mathrm{Y}$ atas $\mathrm{X}$ Tidak Linier.

Setelah diketahui masing-masing variabel penelitian ini, selanjutnya adalah mengukur hubungan antara kegiatan permainan lempar bola terhadap kemampuan motorik kasar anak. Setelah dilakukan pengujian normalitas data pada kedua variabel, diperoleh hasil bahwa kedua data (variabel X dan Y) berdistribusi normal, namun regresinya tidak linier. Maka analisis korelasinya menggunakan analisis statistik non parametrik dengan rumus korelasi Spearman Rank. Adapun langkah-langkah perhitungan menggunakan rumus tersebut adalah sebagai berikut:

a. Koefisien Korelasi. 
Perhitungan ini dimaksudkan untuk mengukur derajat hubungan antara kegiatan permainan lempar bola terhadap kemampuan motorik kasar anak. Setelah dilakukan perhitungan sebagaimana terlampir diperoleh nilai koefisien korelasi r-hitung sebesar 0,76. Koefisien korelasi ini berada pada interval 0,600-0,799 (Kuat/Tinggi), sehingga dapat diinterpretasikan bahwa kegiatan permainan lempar bola dan kemampuan motorik kasar anak memiliki hubungan yang kuat/tinggi.

b. Uji Signifikansi

Selanjutnya dilakukan uji signifikansi koefisien korelasi dengan menggunakan " $\mathrm{t}$ test" dengan rumus:

$$
\begin{aligned}
t & =\frac{r \sqrt{n-2}}{\sqrt{1-r^{2}}} \\
& =\frac{0,76 \sqrt{16-2}}{\sqrt{1-(0,76)^{2}}} \\
& =\frac{0,76 \sqrt{14}}{\sqrt{1-0,578}} \\
& =\frac{0,76 \sqrt{14}}{\sqrt{0,422}} \\
& =\frac{2,84}{0,65} \\
& =4,369 \\
\mathrm{db}=\mathrm{N}-2 & \\
= & 16-2 \\
= & 14
\end{aligned}
$$

Harga t-tabel pada taraf signifikansi 5\% dengan db $=14$ sebesar 2,145

Karena harga thitung $=4,369>$ ttabel $=2,145$, maka Ha diterima. Dengan kata lain ada hubungan yang signifikan antara kegiatan permainan lempar bola terhadap kemampuan motorik kasar anak.

c. Koefisien Determinasi

Pengujian terakhir yaitu menentukan koefisien determinasi untuk mengetahui kontribusi atau sumbangan yang diberikan kegiatan permainan lempar bola terhadap kemampuan motorik kasar anak dengan rumus:

$$
\begin{aligned}
\mathrm{KD} & =\mathrm{r} 2 \times 100 \% \\
& =0,762 \times 100 \% \\
& =0,58 \times 100 \% \\
& =58 \%
\end{aligned}
$$


Berdasarkan hasil yang diperoleh di atas, maka kegiatan permainan lempar bola memberikan kontribusi sebanyak 58\% terhadap kemampuan motorik kasar anak. Artinya masih ada $42 \%$ faktor lain yang mempengaruhi kemampuan motorik kasar anak di kelompok B RA Nurul Bayan Garut.

Hubungan antara kegiatan permainan lempar bola terhadap kemampuan motorik kasar anak ini termasuk ke dalam kategori kuat/tinggi karena berdasarkan penelitian terdapat unsur-unsur pengolahan tubuh yang dapat dikoordinasikan melalui kegiatan permainan lempar bola, tetapi masih terdapat faktor-faktor lain yang mempengaruhi kemampuan motorik kasar anak. Hal ini didukung oleh pendapat Hapsari (2016: 205-207) bahwa perkembangan motorik dipengaruhi oleh beberapa faktor diantaranya yaitu: 1) sifat dasar genetik; 2) kondisi dalam masa pranatal; 3) proses kelahiran; 4) kecerdasan atau iq; 5) lingkungan; 6) stimulus; 7) pola asuh; 8) kesehatan dan cacat fisik.

\section{Penutup}

Berdasarkan hasil penelitian dapat diambil kesimpulan bahwa terdapat hubungan yang signifikansi antara kegiatan permainan lempar bola terhadap kemampuan motorik kasar anak. Kegiatan permainan lempar bola memperoleh nilai rata-rata sebesar 77 termasuk pada kategori baik karena berada pada interval 70-79. Sedangkan kemampuan motorik kasar anak memperoleh nilai rata-rata sebesar 66, termasuk pada kategori cukup karena berada pada interval 60-69. Hubungan antara kegiatan permainan lempar bola terhadap kemampuan motorik kasar anak diperoleh angka koefisien korelasi sebesar 0,76. Angka koefisien korelasi ini termasuk pada kategori kuat/tinggi, karena berada pada interval $0,600-0,799$.

\section{Daftar Pustaka}

Depdiknas. (2007). Pedoman Pembelajaran Bidang Pengembangan Fisik/Motorik di Taman KanakKanak. Jakarta: Direktorat Pembinaan Taman Kanak-kanak dan Sekolah Dasar.

Erlinda, E. (2014). Perkembangan Motorik kasar Anak Usia Dini Melalui Permainan Melempar dan Menangkap bola . Bengkulu: Universitas Bengkulu.

Hapsari, I. I. (2016). Psikologi Perkembangan Anak. Jakarta: Pt. Index.

Hurlock, E. B. (1978). Perkembangan Anak Jilid 1. Jakarta: Gelora Aksara Pratama.

Lismadiana. (2013). Peran Perkembangan Motorik Pada Anak Usia Dini. Yogyakarta: Universitas Negeri Yogyakarta.

Mahendra, A. (2000). Bola Tangan. Jakarta: Depdiknas. 
Mirman, T. T. (2005). Pendidikan Jasmani dan Kesehatan. Jakarta: Universitas Terbuka.

Nata, A. (2003). Kapita Selekta Pendidikan Islam. Bandung: Angkasa Bandung.

Satyaningdharma. (2014, March). East Street. Retrieved from http://satyaningdharma.blogspot.com.

Soeparman, S. d. (1993). Kinesiologi. Jakarta: UT Jakarta dan Depdikbud.

Sudjarwo. (1992). Ilmu Kepelatihan Dasar. Surakarta: Universitas Sebelas Maret.

Suharsimi, A. (2013). Prosedur Penelitian Suatu Pendekatan Praktik. Jakarta: Rineka Cipta.

Sujiono. (2014). Hakikat Perkembangan Motorik Anak. Jakarta: Universitas Terbuka.

Sujiono, B. (2007). Metode Pengembangan Fisik. Jakarta: Universitas Terbuka.

Sukardi. (2003). Metodologi Penelitian Pendidikan. Jakarta: Bumi Aksara.

Sumantri, M. (2005). Model Pengembangan Keterampilan Motorik Anak Usia Dini. Jakarta: Depdiknas.

Sunaryo, S. d. (2007). Intervensi Dini Anak Berkebutuhan Khusus. Jakarta: Depdiknas.

Syah, M. (2003). Psikologi Belajar. Jakarta: PT. Rajagrapindo Persada.

Wiyani, N. A. (2014). Format PAUD Konsep, Karakteristik, \& Implementasi Pendidikan Anak. Usia Dini. Yogyakarta: Ar-Ruz Media. 